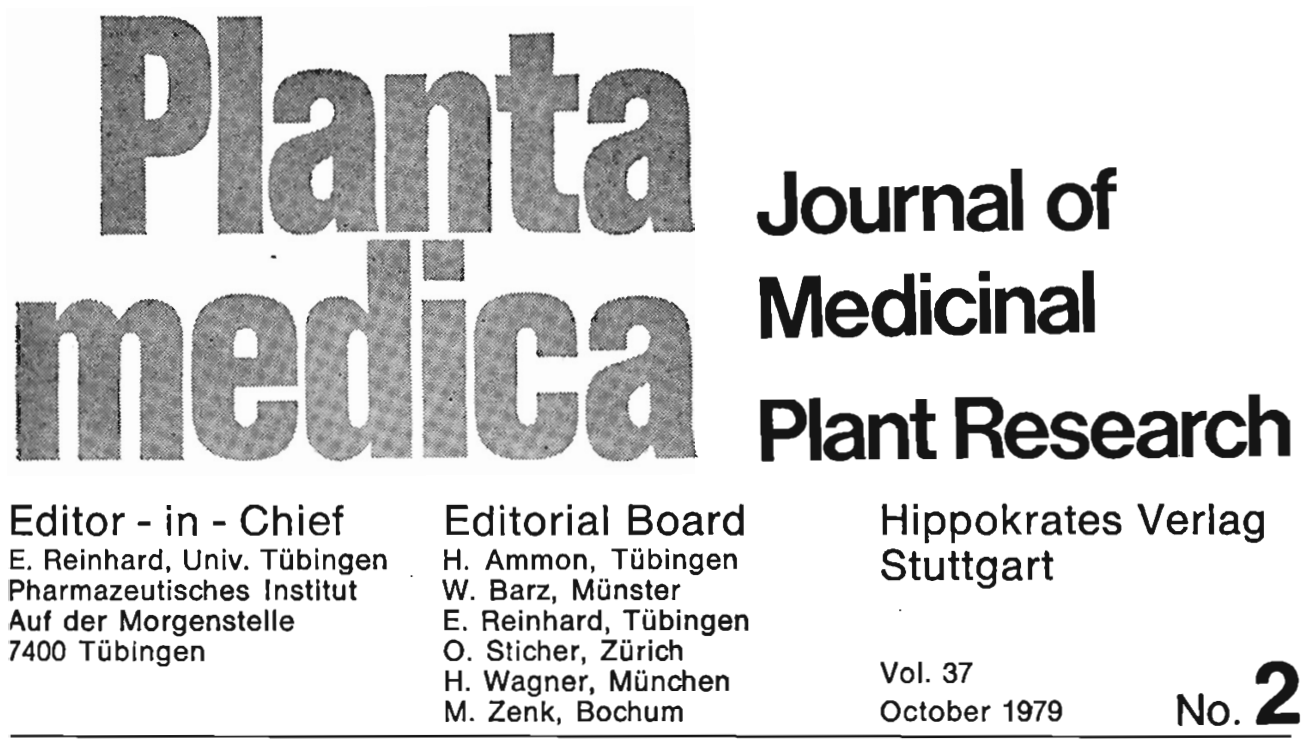

Review AmRiche

\title{
Phenylpropanoid Metabolism
}

\author{
G. H. N. Towers and Chi-Kit Wat
}

Botany Department, The University of British Columbia, Vancouver, B. C.

Key Word Index: Phenylpropanoid; PAL; Cinnamate;P-coumarate; Flavonoid synthase; CoA ligases; Coniferyl Alcohol; Lignins; Chlorogenic Acid; Physiologically Active flavonoids.

\section{Abstract}

Enzymes for the biosyntheses of the major phenylpropanoid derivatives in vascular plants, namely flavonoids, lignins and cinnamyl esters are now known. The cinnamate pathway to these compounds is reviewed briefly and brought up-to-date. Remaining problems, such as the regulation by light and other factors as well as compartmentalization of phenylpropanoid metabolism are being studied in many laboratories. The physiological importance of low molecular weight cinnamyl compounds needs attention.

Pioneer tracer studies by the schools of Neish [24], Freudenberg [24] and 
Grisebach [29] laid much of the basic groundwork essential to an understanding of the biogeneses of phenylpropanoid derivatives in plants at the enzyme and regulatory levels. The discovery of stable enzymes catalyzing the non-oxidative deamination of L-phenylalanine and of L-tyrosine to cinnamic and $\mathrm{p}$ coumaric acids $[66,52]$ attracted phytochemists and plant physiologists to polyphenolic biochemistry, an interest, that continues unabated. The basic enzymology of the important classes of phenylpropanoids or derivatives of cinnamic acid, including the flavonoids and lignins, is in fact now known. This is certainly not true for two other large classes of natural products, namely the alkaloids and the terpenoids.

Important problems remain, however, particularly those concerned with the integration of phenylpropanoid metabolism with primary metabolic processes or the relationship between cell differentiation and regulation of polyphenol production. Regulation is complex in this area of metabolism because of the multibranched pathways leading to a wealth of compounds $[3,49]$.

The subject has been reviewed exten- sively in the last few years $[11,30,34$, $49,89]$ and we hesitate to add yet another review to the list. We will attempt, however, to bring the subject up-to-date and to point to some areas of cinnamate metabolism that need study. A number of attempts have been made to discuss regulation of phenylpropanoid metabolism in terms of cellular compartmentalisation $[3,34,84,85]$. Since this is a subject for a review of its own it will not be dealt with here.

Fig. 1 is a pictorial representation of the extent of flow of carbon into phenylpropanoid compounds in plants, the thickness of the arrows indicating roughly the relative amounts involved. In some plant tissues the amount of carbohydrate involved in lignin biosynthesis, e.g., in xylem or sclerenchyma of seed coats, is considerable. Fig. 2 shows the biochemical relationships of the phenylpropanoids in plants.

The first enzyme in the phenylpropanoid pathway is phenylalanine ammonia lyase (PAL) (E.C.4.3.1.5), the reaction catalyzed being the anti elimination of $\mathrm{NH}_{4}{ }^{+}$and the pro 3S-proton of L-phenylalanine to yield transcinnamic acid (Fig. 3). Preparations

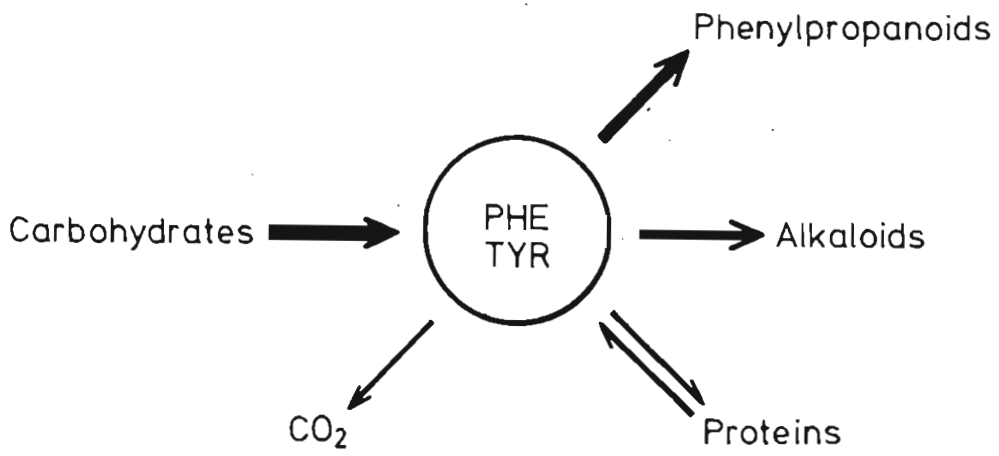

Fig. 1. Carbon flow through phenylalanine (PHE) and tyrosine (TYR) in plants. 


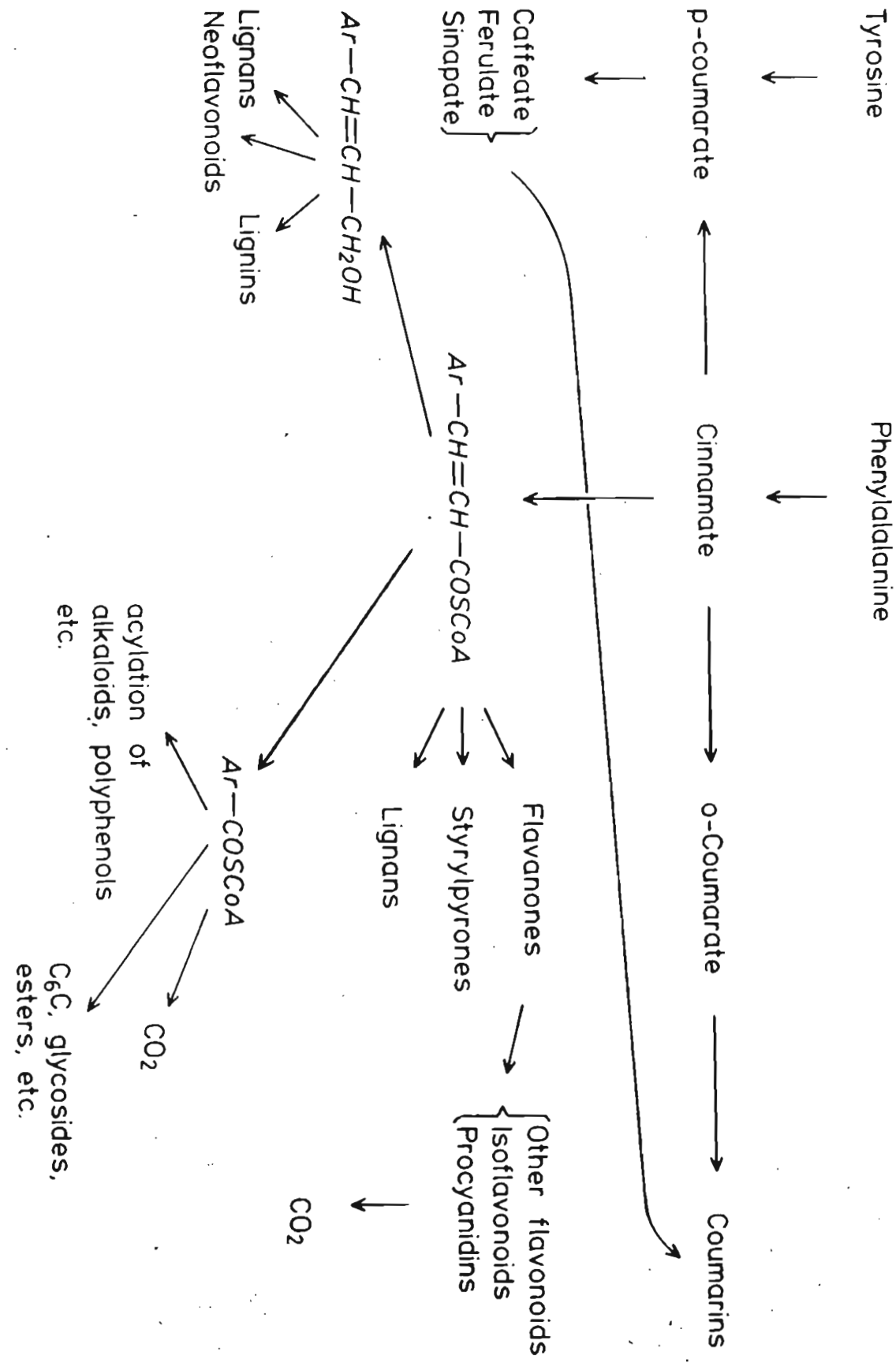

Fig. 2. Metabolism of cinnamate in plants.

from many plant and fungal sources $\mathrm{NH}_{4}{ }^{+}$although always to a lesser exalso catalyze the deamination of L-ty- tent. For example, the electrophoretirosine to trans-p-coumaric acid and cally' homogeneous preparation from 


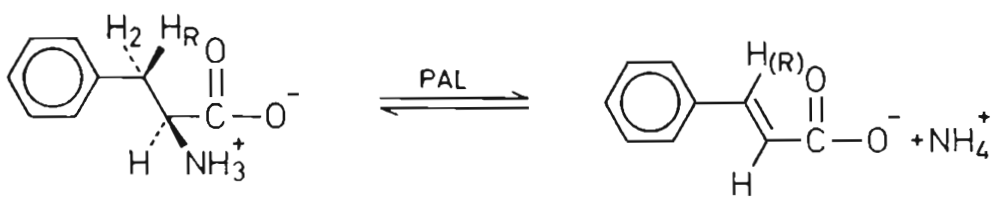

Fig. 3. The reaction catalyzed by phenylalanine ammonia lyase (PAL).

Rhodotorula glutinis has a PAL/TAL ratio of $3: 1$ [26].

The kinetic effects of modification of the substrate are discussed in detail by HANSON and Havir [35]. The reaction sequence is "ordered uni-bi" with cinnamate released before $\mathrm{NH}_{4}{ }^{+}$. A dehydroalanine-containing electrophilic prosthetic group at the active site combines with the amino group of phenylalanine/tyrosine [35]. There is also evidence for a firmly bound transition metal ion at the active site [16].

Because cinnamate is at a branch point in phenylpropanoid metabolism (Fig. 2) it might be expected that PAL has regulatory properties. The enzyme consists of two protomers each consisting of two polypeptide chains and appears to follow a partially concerted mechanism of subunit interactions [65]. It is negatively rate co-operative with respect to L-phenylalanine and is inhibited by trans-cinnamate [65]. From theoretical considerations LAMB and RUBERY [5.3] deduce that PAL should be more sensitive to events in the phenylpropanoid pathway and less sensitive to changes in the steady-state concentration of L-phenylalanine. In other words, fluctuations in phenylalanine concentration in the cell caused by changes in either its rate of incorporation into proteins or its rate of biosynthesis via the shikimate-chorismate pathway should not affect rates of cinnamate produc- tion. MARGNA, on the other hand, concludes that control is at the level of substrate supply [58]. Interest in this enzyme by physiologists and enzymologists continues and we will not attempt to cover the more recent literature. There are, however, some reports on this enzyme which are of medical interest.

Highly purified PAL (also active with tyrosine), from the yeast, Rhodotorula glutinis, is available commercially and is suitable for the estimation of phenylalanine and tyrosine in as little as $20 \mu \mathrm{l}$ of serum or plasma by the method of SHEN and Abell [78]. This is a potentially important method in periodic determinations of phenylalanine in the screening of newborn infants in connection with phenylketonuria. A highly purified preparation from the same source has been used to raise antisera in rabbits and the antigen-antibody complex was found to be enzymatically active in vitro [1,81]. PAL produced cures in mice inoculated with L5178Y lymphoblastic leukemia [2]. The biological half-life of the enzyme, after a single injection, was approximately 21 hours in mice, rats and monkeys but was considerably reduced upon repeated administration [26]. This was especially marked in tumor-bearing mice. Attempts are being made to modify the enzyme to make it non-immunogenic or to increase its half life [26]. 
With many plant tissues, light has becn shown to have a stimulatory effect on the levels of enzymes of phenylpropanoid metabolism, including PAL [82]. One of the best illustrations of this light effect on PAL is the classical experiment of ZUCKER [93] with potato tuber discs in which there is a $2-3$ fold increase in light-treated discs over dark controls. Phytochrome is commonly invoked in this regulation. Although de novo synthesis of PAL has been demonstrated in light-treated plant materials $[42,74$, 76,] there is evidence that the light-induced increase in PAL is the result of activation of a previously synthesized protein and that the effect of irradiation does not alter the rate of enzyme synthesis $[20,43,77]$. SCHRÖder has shown that the amount of mRNA for PAL, which is very low in dark-grown parsley cell cultures, increases on irradiation and the rate of appearance of active enzyme is controlled by the concentration of $m$ RNA in the polyribosomes [77]. The light-induced increase of mRNA for PAL may also be explained by either a stimulation in the rate of de novo synthesis or a reduced ratc of degradation of the $\mathrm{m}$ RNA after the beginning of irradiation.

A final point about this enzyme: although PAL and TAL activities are not separable, the ratios of activities differ in time in plant materials [26] or in fungi [10]. There is cvidence for the presence of isoenzymes of PAL as well as for the presence of isoenzymes with different PAL/TAL ratios [47] which may explain these observations.

Cinnamic acid exists as photochemically interconvertible gcometric isomers. Usually the cis-derivatives are physiologically active, e.g., methyl 3,4dimethoxy-cis-cinnamate is a uredospore germination inhibitor from the sunflower rust (Puccinia helianthi) or bean rust (Uromyces phaseoli) whereas the trans isomer is inactive. Allergic reactions to cinnamic acid and cinnamyl esters have been reported in relation to sensitivity to balsam of Peru [40], once considered an ideal panacea for parasitic skin diseases in poorer socicties in S. America. Cinnamates are well known to the dermatologist as sensitizers in allergic photodermatitis [23].

The known biochemical reactions of cinnamic acid in plants are shown in Fig. 4. Each of the products is of interest but we will briefly mention one of these, namely 4-hydroxylation and concentrate on ester formation because the coenzyme A esters of cinnamic and hydroxycinnamic acids are precursors of many of the chief phenolic constituents of plants.

Experiments with seedlings of Zca mays grown in light, in an atmosphere cnriched with oxygen-18 showed that the hydroxyl oxygen atom in p-coumaric acid is derived from molecular oxygen [25]. The hydroxylation reaction involves the transfer of electrons from reduced pyridine nucleotides via the enzyme NADPH:cytochrome P-450 reductase to the terminal oxidase cytochrome P-450 and this multienzyme complex is localized in the microsomal fraction [6]. Evidence for an clectrophilic intermediate, possibly an epoxide, is indicated in the reaction (Fig. 5). In the presence of glutathione the intermediate is trapped as a glutathione Scinnamyl adduct [15] Cinnamyl CoA ligases catalyze the following types of reaction: 
<smiles>O=C(O)CC(O)c1ccccc1</smiles><smiles>O=S(=O)(O)/C=C/c1ccccc1</smiles><smiles>O=C(O)CCc1ccccc1</smiles>
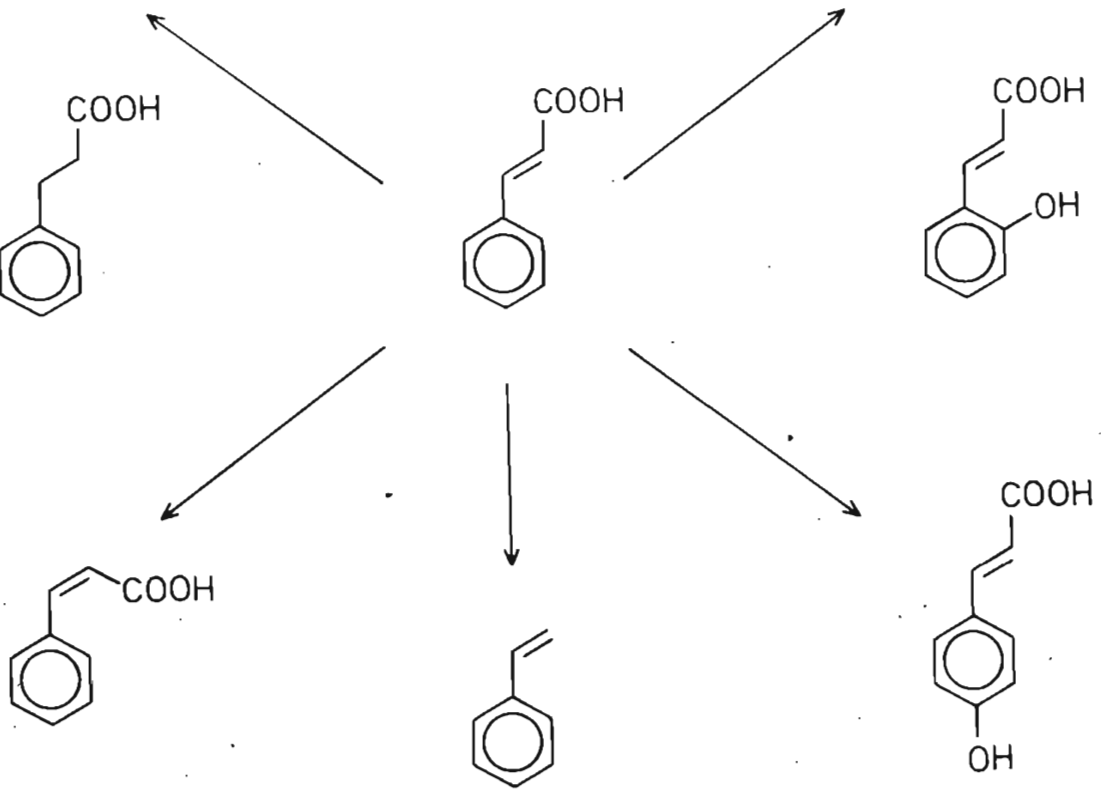

Fig. 4. Biochemical reactions of trans-cinnamic acid.

Fig. 4. Biochemical reactions of trans-cinnamic acid.
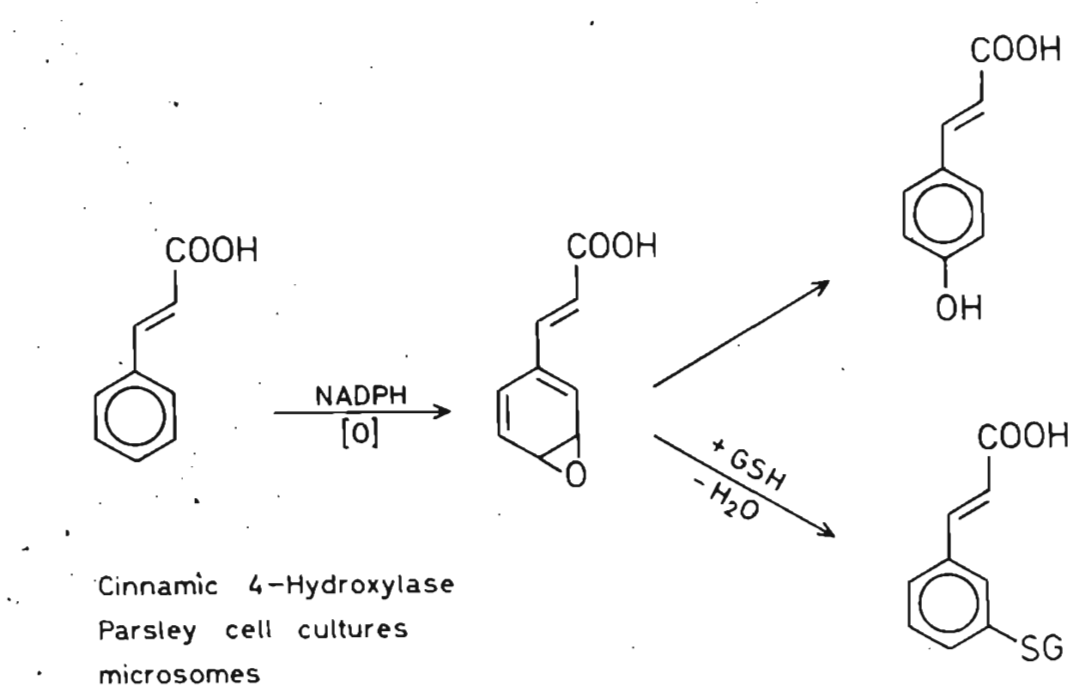

Fig. 5. Reaction catalyzed by cinnamic-4-hydroxylase [15]. 
$\mathrm{Ar}-\mathrm{CH}=\mathrm{CH}-\mathrm{CO}_{2} \mathrm{H}+\mathrm{ATP}+\mathrm{CoASH}$ $z \mathrm{ArCH}=\mathrm{CH}-\mathrm{COSCoA}+\mathrm{AMP}+\mathrm{P}-\mathrm{P}$

The coenzyme $A$ esters are central compounds in the metabolism of phenylpropanoids (Fig. 6). Surveys of plants for hydroxycinnamate: CoA ligases $[32,39,50,69,92]$ indicate the occurrence of isoenzymes [51] as well as differences in substrate specificities of preparations from different species (see [89] for references). As an example, the partially purified, electrophoretically homogeneous preparation from cell suspension cultures of parsley was shown to be most active with trans-p- coumarate and showed homotropic, allosteric effects [50]. The molecular weight was estimated to be around 67,000 .

A hydroxycinnamate: CoA ligase and a transferase which together catalyze the esterification of p-coumarate to $5^{\prime}$ p-coumarylquinate and of caffeate to chlorogenate have been purified from tomato fruits [70]. Both the ligase and the transferase show higher affinity for the monohydroxy cinnamyl substrates than the dihydroxy ones. The transferase is reversible. p-Coumarylquinic hydroxylase has also been identified in to-

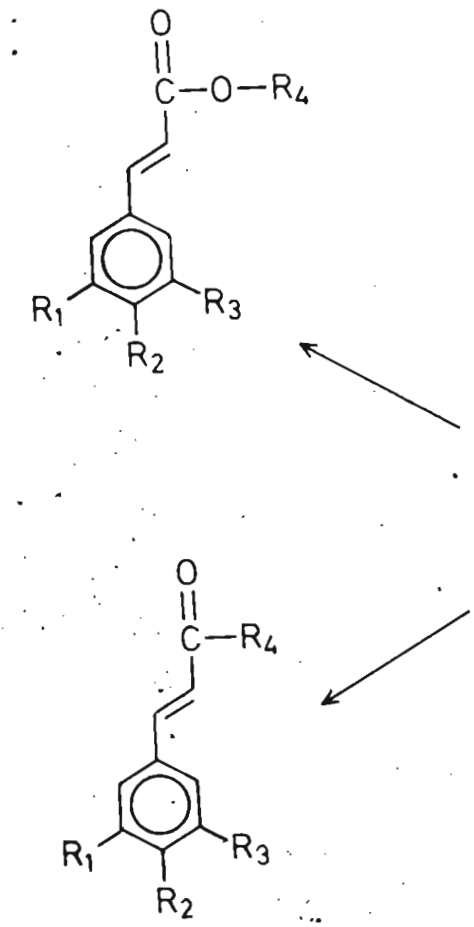

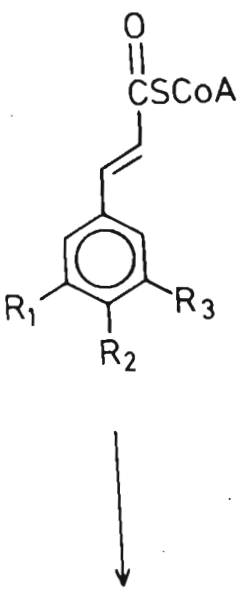
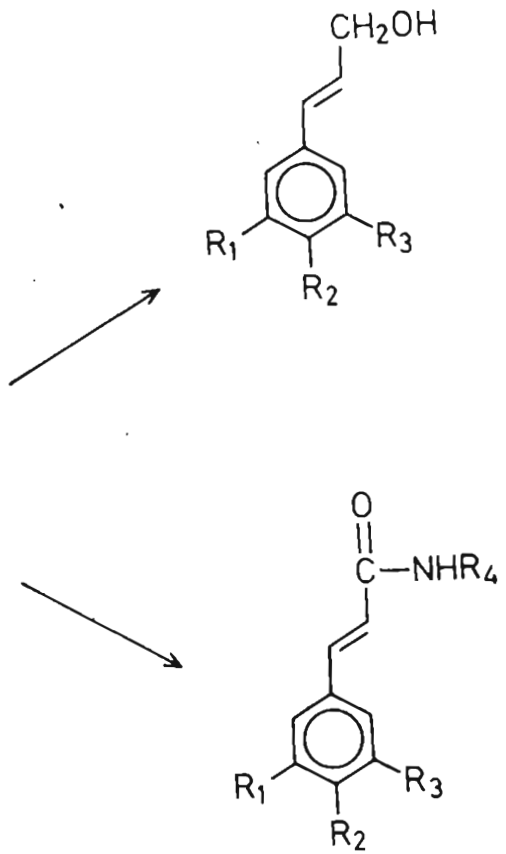<smiles>[R]c1cc(C(=O)O)cc([R])c1[R]</smiles>

Fig. 6. General reactions of cinnamyl and hydroxycinnamyl CoA esters in plants $\left(\mathrm{R}_{1}, \mathrm{R}_{3}=\mathrm{H}, \mathrm{OH}, \mathrm{OCH}_{3} ; \mathrm{R}_{2}=\mathrm{H}, \mathrm{OH} ; \mathrm{R}_{4}=\right.$ variable $)$. 


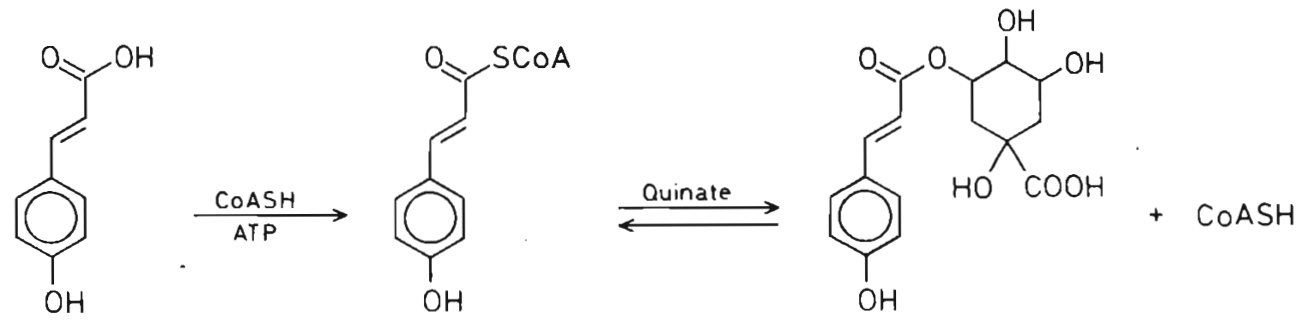

$\downarrow$
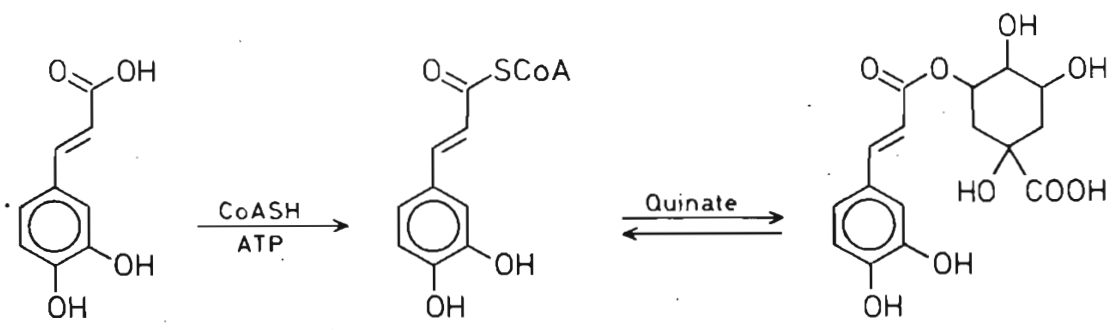

$+\mathrm{COASH}$

Fig. 7. Biosynthesis of chlorogenic acid in tomato fruits [70].

mato fruits $[36,56]$ so that there are two possible routes to the synthesis of chlorogenic acid (Fig. 7). The transferase has been identified in isolated chloroplasts of Petunia [68].

Whereas some esters, like chlorogenic acid and its isomers are found in almost all vascular plants, others are more restricted in distribution. Acylation of flavonoids [88], carbohydrates [59], proteins [90] and lignins [79] by hydroxycinnamic acids is commonly observed but the enzymes involved have not been studied. A few selected esters of cinnamic and hydroxycinnamic acids are shown in Fig. 8. They include esters of an alkaloid [64], a diterpene [91], a long chain alcohol.[13] and the very common quinyl ester, chlorogenic acid.

Three isoenzymes of hydroxycinnamate: CoA ligase, with differing substrate specificity were identified in leaves of Petunia [69]. In addition to p-coumarate each enzyme acted on one of caffeate, ferulate or sinapate. Each enzyme exhibited non-competitive inhibition with different phenolic compounds, a feature consistent with an isoenzyme regulation of phenylpropanoid pathways leading to esters, flavonoids and lignins.

The coenzyme A esters of cinnamic acids serve as starter molecules in a process analogous to polyketide or fatty acid biosynthesis in which acetyl CoA is the terminus of the chain. This agrees with the original hypothesis of BiRcH and Donovan [8]. The side chain of the cinnamic acid may be extended by 1,2 , $4,5,6,7$, or 12 carbons (Fig. 9), the commonest molecules (the typical flavonoids) being those with the equivalent of three acetyl units added on, i.e., six carbons. From the laboratories of 
<smiles>COC(=O)/C=C\c1ccc(OC)c(OC)c1</smiles>

Methyl-3,4-dimethoxy

cis-cinnamate

Uromyces phaseoli

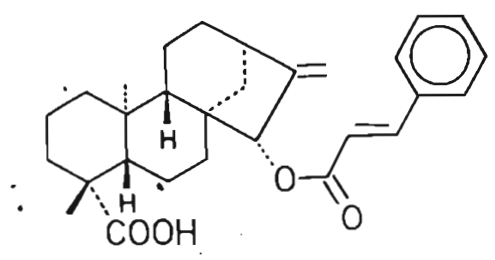

Cinnamyl grandifloric

acid

Mikania oblongifolia<smiles>[R20]Oc1ccc(/C=C/C(=O)OC[C@@H]2CCCN3CCCC[C@@H]23)cc1</smiles>

(-) (Trans -4'-rhamnosyloxycinnamyl)

lupinine

Lupinus luteus<smiles>O=C(/C=C/c1ccc(O)c(O)c1)O[C@H]1C[C@@](O)(C(=O)O)C[C@H](O)[C@H]1O</smiles>

Chlorogenic acid

Common<smiles>[R4]C(C)(C)C(C)(C)COC(=O)/C=C/c1ccc(O)c(OC)c1</smiles>

Hexacosyi ferulate

Pinus roxburghii

Fig. 8. Examples of naturally occurring cinnamyl and hydroxycinnamyl esters in plants and fungi.

GrisebaCH and HAHLBROCK at Freiburg have come the most detailed studies to date on flavonoid biosynthesis with enzyme preparations [19, 34, 38]. Flavanone synthase, which catalyzes the formation of naringenin from p-coumaryl CoA and malonyl CoA (Fig. 10) has been obtained from parsley, soybean and Haplopappus [75] cell suspension cultures as well as from anther extracts of Tulipa [87]. It has also been detected in isolated chloroplasts of Petunia [68]. Under certain conditions styrylpyrones $\left(\mathrm{C}_{13}\right)$ or benzalacetones $\left(\mathrm{C}_{11}\right)$ are for- 
<smiles>O=C1C=CCC(c2ccc(O[AlH2])cc2)O1</smiles>

Psilotin

Psilotum nudum<smiles>Oc1ccc(C=Cc2cc(O)cc(O)c2)cc1</smiles>

Resveratrol

Rheum rhaponticum<smiles>COc1cc(/C=C/c2ccccc2)oc(=O)c1</smiles>

dehydrokawain

Piper methysticum<smiles>O=c1c(O)c(-c2ccc(O)c(O)c2)oc2cc(O)cc(O)c12</smiles>

Quercetin

Common<smiles>COc1cc(/C=C/C2=COPC(/C=C/c3ccc(O)c(OC)c3)=C2)ccc1O</smiles>

Curcumin

Curcuma longa<smiles>CCCCCC(O)CC(=O)CCc1ccc(O)c(OC)c1</smiles>

Gingerols

Zingiber officinalis<smiles>O=C(O)C=Cc1ccc(O)cc1</smiles>

Cortisalin

Corticium salicinum

Fig. 9. Examples of naturally occurring compounds in plants and fungi derived from cinnamate and acetate.

med, particularly with caffeyl $\mathrm{CoA}$ as studies, the regulation of flavonol glystarter molecule [38]. In some elegant coside biosynthesis in parsley cell sus- 
pension cultures, as it is affected by light, has been examined (see [19] and [34] for details). Other flavonoids such - as certain flavonol glycosides are derived, in turn, from naringenin by specific enzymes.

Enzymes concerned with anthocyanidin biosynthesis have not yet been discovered but their genesis, in vivo from dihydroflavonols (Fig. 11) has been clearly demonstrated [23a, 46].

Related to the flavonoids are the stilbenes, a group of compounds in which the extended side chain of cinnamic or a hydroxycinnamic acid undergoes a 2,7cyclisation or an intramolecular aldol reaction rather than a 1,6-cyclisation as in the formation of regular flavonoids. The two benzene rings are linked by a 2-carbon bridge. The terminal carboxyl group may be retained, as in hydrangenol, or lost as in resveratrol (Fig. 12). The correct biogenetic origins of hydrangenol and of resveratrol, already established in tracer experiments $[7,41]$, have now been verified with enzyme

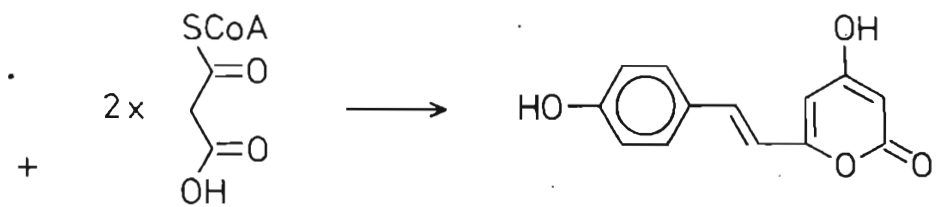

bis-noryangonin
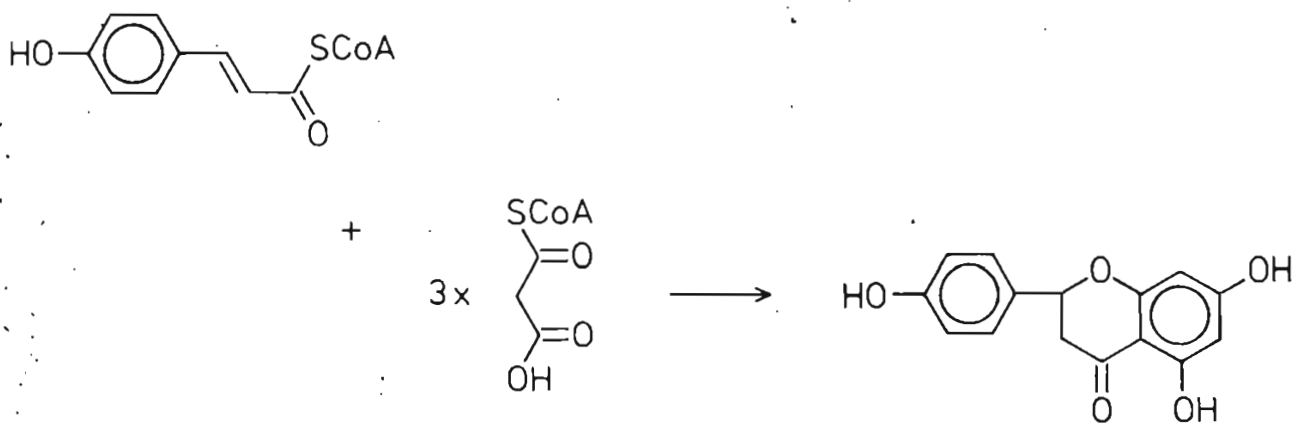

naringenin

Fig. 10. Biosynthesis of the flavanone, naringenin, and the styrylpyrone, bis-noryangonin, by flavanone synthase in plants. [38].<smiles>[R]c1cc([C@H]2Oc3cc(O)cc(O)c3C(=O)[C@H]2O)cc([R])c1[R]</smiles>

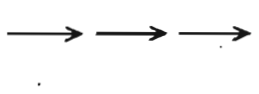

$\mathrm{R}_{1}, \mathrm{R}_{2}+\mathrm{R}_{3}=\mathrm{H}, \mathrm{OH}$<smiles></smiles>

anthocyanidin

trans-2,3-dihydroflavonol

Fig. 11. Formation of anthocyanidins from. dihydroflavonols in Petunia. 
<smiles>O=C(/C=C/c1ccc(O)cc1)S(=O)(=O)O</smiles><smiles>O=C(O)CC(=O)O[Na]</smiles>

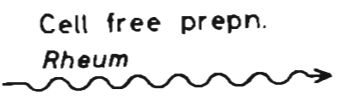<smiles>Oc1ccc(/C=C/c2cc(O)cc(O)c2)cc1</smiles>

resveratrol

Fig. 12. Biosynthesis of resveratrol from p-coumaryl:CoA and malonyl:CoA with cell-free preparations of Rheum rhaponticum rhizomes. [73].<smiles>O=C(O)CC(=O)CC(=O)O[Mg]</smiles><smiles>O=C(C=Cc1ccc(O)cc1)CC(=O)S(=O)O[Na]</smiles><smiles>COCCO</smiles><smiles>COc1cc(/C=C/C(=O)/C=C(O)/C=C/c2ccc(O)c(OC)c2)ccc1O</smiles>

Fig. 13a. Suggested biogenetic scheme for curcumin in Curcuma longa [72].

preparations $[48,73]$. The stilbene syn- bound. The reaction is shown in Fig. 12. thase of Rheum rhaponticum rhizomes, Not so readily resolved is the prowhich catalyzes the formation of res- blem of the biogenesis of curcumin, the veratrol from p-coumaryl CoA and ma- yellow pigment of Curcuma longa lonyl CoA, was found to be membrane (Turmeric). This phenylpropanoid, with 
<smiles>O=C(O)CC(=O)S[13C](=O)[O-]</smiles><smiles>CCCCCCCCCCCCCCCCCC(=O)CC(=O)OC(=O)CC(=O)CC(=O)C=Cc1ccc(O)cc1</smiles><smiles>COc1cc(/C=C/C2=COCC(/C=C/c3ccc(O)c(OC)c3)=C2)ccc1O</smiles>

Fig. 13b. Alternative scheme for biogenesis of curcumin in Curcuma longa [72].

a 1,7-diaryl skeleton, can be considered to be biosynthesized from two phenylpropane moieties with a central carbon originating from acetate or malonate [28]. Tracer experiments do not provide satisfactory support for this biogenetic scheme [72]. Roughley and WHITING [72] have suggested other interpretations, one of which is shown in Fig. 13. There are a number of related compounds in Curcuma as well as in plants of other families but no studies have been made of their biogenesis.

Two examples of an ever growing number of di-and poly-amine conjuga- tes of cinnamic acids [83] are shown in Fig. 14. These are maytenin [21] from a member of the Celastraceae and a cinnamylputrescine derivative from a member of the Liliaceae [71]. Nothing is known as yet about the biosynthesis of this type of compound. Presumably the formation of the amide linkages requires an activated cinnamic acid moiety, e.g., CoA or phosphate ester.

Two enzymes are involved in the reduction of cinnamyl: CoA ester to the corresponding alcohols, compounds which are the basic units of lignins. The enzyme-catalyzed reductions are: 


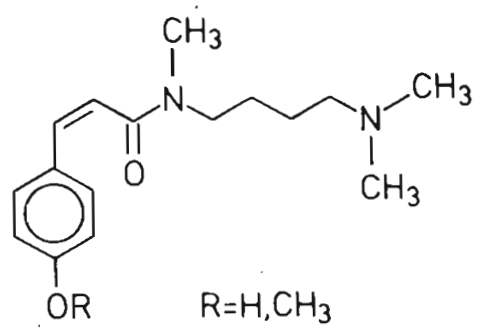

$N, N, N^{*}-$ Trimethyl (4-hydroxy-cis-cinnamyl) putrescine

Kniphofia spp. (Liliaceae)

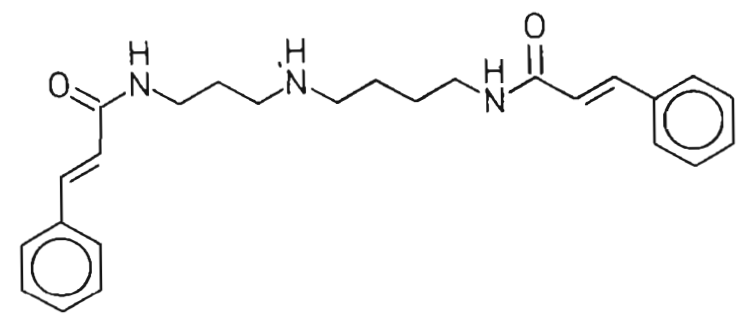

Maytenin (di-trans-cinnamyl spermidine)

Maytenus chuchuhuasho (Celastraceae)

Fig. 14. Two examples of di- and poly-amine conjugates of cinnamic and hydroxycinnamic acid in plants.

(1) $\mathrm{Ar}-\mathrm{CH}=\mathrm{CH}-\mathrm{COSCoA}+$

$\mathrm{NADPH}+\mathrm{H}^{+} \gtrless \mathrm{Ar}-\mathrm{CH}=\mathrm{CH}-$

$\mathrm{CHO}+\mathrm{NADPH}+\mathrm{CoASH}$

(2) $\mathrm{Ar}-\mathrm{CH}=\mathrm{CH}-\mathrm{CHO}+\mathrm{NADPH}+$

$\mathrm{H}^{+} \rightleftarrows \mathrm{Ar}-\mathrm{CH}=\mathrm{CH}-\mathrm{CH}_{2} \mathrm{OH}+$

NADP.

The three alcohols, p-hydroxycinnamyl, coniferyl and sinapyl alcohols undergo polymerisation with peroxidase to form the complex heteropolymers known as angiosperm or hardwood lignins. Gymnosperm lignins rarely contain sinapyl units but have predominantly coniferyl or guaiacyl nuclei. The biochemistry of lignification has been reviewed recently [30]. Cell-wall-bound peroxidases are possibly important [31] and the possibilitity that multienzyme complexes are involved in lignification [84] is appealing. Lignification, like flavonoid production, is a rapid process, subject to easy perturbation by chemical and physical factors of many kinds. Regulation, in vivo, is likely to be a very complicated process because it is closely tied to cell differentiation, particularly xylogenesis or development of xylem [33].

Before leaving the phenylpropanoids mention should be made of their physiological activities in various biological systems. In addition to their roles as phytoalexins, chemical messengers for pollination, insect deterrents and so on $[22,61]$ some of the flavonoids have unusual properties. The significance in 
many instances may be simply acciden- in higher plants [86]. Chamanetin, also tal. Thus phloridzin, which is present, in shown in Fig. 15, a C-benzylated flalarge amounts, in all parts of apple trees vanone from Uvaria chamae (Anona(Malus spp.) except for the edible part ceae) is cytotoxic and antineoplastic of the fruit, interferes with sugar trans- [55]. Rotenone and related compounds port in animal tissues. It competes with in species of Lonchocarpus and other lesugars for a common membrane binding guminous plants, has long been known site [5]. It gives no corresponding effects as an excellent insecticide. The roten-<smiles>O=C(CCc1ccc(O)cc1)c1c(O)cc(O)cc1O</smiles><smiles>Oc1ccc(CC=Cc2ccccc2)cc1</smiles>

Phloridzin

Malus spp.

Obtusastyrene

Dalbergia spp.<smiles>C=CC(C1=CC(=O)C(OC)=CC1=O)c1ccc(OC)c(OC)c1</smiles>

3,4-Dimethoxydalbergione

Dalbergia spp., Machaerium spp.<smiles>O=C1C[C@H](c2ccccc2)Oc2c(Cc3ccccc3O)c(O)cc(O)c21</smiles>

Chamanetin

Uvaria chamae<smiles>C=C(C)C1Cc2c(ccc3c2OC2COc4cc(OC)c(OC)cc4C2C3=O)O1</smiles>

Rotenone

Lonchocarpus spp.

Fig. 15. Examples of physiologically active flavonoids from plants. 
oids have a low toxicity to mammals but are potent inhibitors of mitochondrial oxidation in insects and fish [27]. Obtusastyrene, a cinnamyl phenol from another legume, Dalbergia, is antibacterial, antifungal, antialgal and also damages plant cell membranes $[12,18$, $44,45]$. It could be useful as a chemical probe in studies of biological membranes. Other neoflavonoids from Dalbergia and Machaerium, occurring in heartwood, are potent sensitizers in allergic contact dermatitis $[17,63]$. These few examples, seen in Fig. 15 suggest that many other flavonoids might be studied profitably for their biological activities. The toxicity of phenylpropanoids, including flavonoids, is discussed by SinGLeton and Kratzer [80]. Certainly, we should learn more about some of these. Nearly all fruits and vegetables have caffeic acid and other cinnamic derivatives in the range $100-300 \mathrm{mg} / \mathrm{kg}$ fresh weight and may have; as much as 500 $\mathrm{mg} / \mathrm{kg}$ of flavonoids as well [80]. Even coffee and tea may contribute as much as $1 \mathrm{~g}$ of total phenols per day. The effects, if any, of these regular dietary sources of polyphenols on the physiology of man are not known.

\section{References}

1. Abell, C. W., W. J. Smith and D. S. Hodgins: Cancer Res., 32, 285 (1972).

2. Abell, C. W., D. S. Hodgins and W. J. Stith: Cancer Res., 33, 2529 (1973).

3. Alibert, G., R. Ranjeva and A. M. Boudet: Physiol. Veg., 15, 279 (1977).

4. Allen, P. J.: Proc. Nat. Acad. Sci. USA. 69, 3497 (1972).

5. Alvarado, F.: Biochim. Biophys. Acta, 135, 483 (1967).

6. Benveniste, I., J.-P. Salaun and F. Durst: Phytochem., 17, 359 (1978).
7. Billek, G. and H. Kindl: Monatsch. Chem., 93, 814 (1962).

8. Birch, A. J. and F. W. Donovan: Aust. J. Chem., 6, 360 (1953).

9. Borsche, W. and W. Peitzsch: Ber. Disch. Chem. Ges. 63, 2414 (1930).

10. Camm, E. L. and G. H. N. Towers: Phytochem., 8, 1407 (1969).

11. Camm, E. L. and G. H. N. Towers: In Progress in Phytochemistry L. Reinhold, J. B. Harborne and T. Swain (Eds.): Vol. 4, 1977, Pergamon Press.

12. Chan, B. G. and L. Jurd: Experientia, 29, 1196, (1973).

13. Chatterjee, A., K. P. Dhara, R. N. Rej, P. C. Ghosh: Phytochem., 16, 397 (1977).

14. Connell, D. W. and M. D. Sutherland: Austral. J. Chem., 22, 1033 (1969).

15. Diesperger, $H$. and $H$. Sandermann: FEBS Letts., 85, 333 (1978).

16. Dixon, N. E., C. Gazzola, R. L. Blakeley and B. Zerner: Science, 191, 1144 (1976).

17. Donnelly, D. M. X.: In J. B. Harborne, T. Mabry and H. Mabry (eds.): The Flavonoids, pp. 843, London 1975, Chapman \& Hall.

18. Dupuis, G., B. Johri, R. J. Bandoni and G. H. N. Towers: Can. J. Microbiol., 18, 929 (1972).

19. Ebel, J. and K. Hahlbrock: Eur. J. Biochem., 75, 201 (1977).

20. Engelsma, G.: Plant Physiol., 54, 702 (1974).

21. Englert, G., K. Klinga, R. Hamet, E. Schlittler and W. Vetter: Helv. Chim. Acta 56, 474 (1973).

22. Farnsworth, N. R. and G. A. Cordell: Lloydia, 39, 420 (1976).

23. Fisher, A. A.: Contact Dermatitis, Philadelphia, 448 pp. (1973). 2nd Edition Lea \& Febiger.

23a. Forkmann, G.: Planta, 137, 159 (1977).

24. Freudenberg, K. and A. C. Neish: Constitution and Biosynthesis of Lignin, New York 1968, Springer Verlag.

25. Fritz, G. J. and B. D. Andersen: Phytochem., 17, 581 (1978).

26. Fritz, R. R., D. S. Hodgins and C. W. Abell: J. Biol. Chem. 251, 4646 (1976).

27. Fukami, H. and M. Nakajimi: In M. Jacobsen and D. G. Crosby (eds.): Naturally Occurring Insecticides, pp. 71. N. Y. 1971. Marcel Dekker Inc. 
28. Geissman, T. A. and D. H. G. Crout: Organic Chemistry of Secondary Plant Metabolism, San Francisco 1969, Freeman, Cooper and Co.

29. Grisebach, H.: Biosynthetic Patterns in Microorganisms and Higher Plants, New York 1967, J. Wiley and Sons.

30. Grisebach, H.: Naturwissen., 64, 619 (1977).

31. Gross, G. G. and C. Janse: Z. Pflanzenphysiol., 84, 447 (1977).

32. Gross, G. G., R. L. Mansell and M. H. Zenk: Biochem. Physiol. Pflanzen, 168, 41 (1975).

33. Haddon, L. and D. H. Northcote: Planta, 128, 255 (1976).

34. Hahlbrodk, K.: In "Barz, W., E. Reinhard and M. H. Zenk (eds.): Plant Tissue Culture and its Bio-technological Application, p. 95, Berlin, Heidelberg, 1977, Springer Verlag.

35. Hanson, K. R. and E. A. Havir: Archiv. Biochem. Biophys., 180, 102 (1977).

36. Hanson; K. R. and M. Zudker: J. Biol. Chem., 238, 1105 (1963).

37. Haslam, E.: Phytochem., 16, 1625 (1977).

38. Hrazdina, G., F. Kreuzaler, K. Hahlbrodk and $\mathrm{H}$. Grisebach: Archiv. Biochem. Biophys., 175, 392 (1976).

39. Heinzmann, U., U. Seitz and U. Seitz: Planta, 135, 313 (1977).

40. Hjorth, N.: Munksgaard Press, 216 pp. Copenhagen, 1961.

41. Ibrahim, R. K. and G. H. N. Towers: Can. J. Biochem. Physiol., 40, 449 (1962).

42. Iredale, S. and H. Smith: Phytochem., 12, 2145 (1973).

43. Johnson, C. B., T. H. Altridge and $H$. Smith: Biochem. Biophys. Acta, 385, 11 (1975).

44. Jurd, L., A. D. King, K. Mihara and W. L. Stanley: Appl. Microbiol., 21, 507 (1971).

45. Jurd, L., K. L. Stevens, A. D. King and K. Mihara: J. Pharm. Sci. 60, 1753 (1971).

46. Kho, K. F. F.: Phytochem., 17, 245 (1978).

47. Kindl, H.: Physiol. Chem. 351, 792 (1970).

48. Kindl, H.: Hoppe-Seyler's Z. Physiol. Chem. 352, 767 (1971).

49. Kindl, H.: Naturwissen., 58, 554 (1971).

50. Knobloch, K.-H. and K. Hahlbrodk: Europ. J. Biochem., 52, 311 (1975).

51. Knobloch, K.-H. and K. Hahlbrodk: Archiv, Biochem., Biophys., 184, 237 (1977).
52. Koukol, J. and E. E. Conn: J. Biol. Chem., 236, 2692 (1961).

53. Lamb, C. J., P. H. Rubery: J. theor. Biol., 60, 441 (1976).

54. Lampe, V., B. Milobedzka and St. v. Kostanecki: Ber., 43, 2163 (1910).

55. Lasswell, W. L. and C. D. Hufford: J. Org. Chem., 42, 1295 (1977).

56. Levy, C. C. and M. Zudker: J. Biol. Chem., 235, 2418 (1960).

57. Macko, V., R. C. Staples, P. J. Allen and J. A. A. Renwidk: Science, 173, 835 (1971).

58. Margna, U.: Phytochem., 16, 419 (1972).

59. Markwalder, H. U. and H. Neukom: Phytochem., 15, 836 (1976).

60. Marshall, D. and M. C. Whiting: J. chem. Soc., p. 537 (1957).

61. McClure, J. W.: In J. B. Harborne, T. J. Mabry and H. Mabry (eds.): The Flavonoids. pp. 970 (1975), Academic Press.

62. McInnes, A. G., S. Yoshida and G. H. N. Towers: Tetrahedron, 21, 2939 (1965).

63. Mitchell, J. C.: Int. J. of Dermat., 14, 301 (1975).

64. Murakoshi, I., F. Kakegawa, K. Toriizuka, J. Haginiwa, S. Ohmiya and H. Otomasu: Phytochem., 16, 2046 (1977).

65. Nari, J., C. Mouttet, F. Fouchier and J. Ricard: Eur. J. Biochem., 41, 499 (1974).

66. Neish, A. C.: Phytochemistry, 1, 1 (1961).

67. Rabino, I., A. L. Mancinelli and K. M. Kuzmanoff: Plant Physiol., 59, 569 (1977).

68. Ranjeva, R., G. Alibert and A. M. Boudet: Plant Science Letts., 10, 235 (1977).

69. Ranjeva, R., A. M. Boudet and R. Faggion: Biochimie, 58, 1255 (1976).

70. Rhodes, M. J. C. and L. S. C. Wooltorton: Phytochem., 15, 947 (1976).

71. Ripperger, H., H. Budzikiewicz and $K$. Schreiber: Biochem. und Physiol. Alkaloide, p. 129, 4th Int. Symp, Berlin. 1972. Akademie Verlag.

72. Roughley, P. J. and D. A. Whiting: J. Chem. Soc., 2379 (1973).

73. Ruprich, N. and H. Kindl: Hoppe-Seyler's Z. Physiol. Chem. 359, 165 (1978).

74. Sacher, J. A., G. H. N. Towers and D. D. Davies: Phytochem., 11, 2383 (1972).

75. Saleh, N. A. M., H. Fritsch, F. Kreuzaler and H. Grisebach: Phytochem., 17, 183 (1978).

76. Schopfer, P. and B. Hock: Planta, 96, 248 (1971). 
77. Schröder, J.: Archiv. Biochem. Biophys., 182, 497 (1977).

78. Shen, R. and C. W. Abell: Science, 197, 665 (1977).

79. Shimada, M., T. Fukuzuka and T. Higuchi: Tappi, 54, 72 (1971).

80. Singleton, V. L. and F. H. Kratzer: In Toxicants occuring naturally in Foods. $\mathrm{Na}$ tional Academy of Sciences. Washington. 1973. pp. 309.

81. Stith, W. J., D. S. Hodgins and C. W. Abell: Cancer Res., 33, 966 (1973).

82. Smith, H.: In Milborrow, B. V. (ed.): Biosynthesis and its control in Plants. pp. 303, London, 1973, Acad. Press.

83. Smith, T. A.: In Reinhold, L., J. B. Harborne and T. Swain (eds.): Progress in Phytochemistry, Vol. 4, 1977, Pergamon Press.

84. Stafford, H. A.: Recent Adv. Phytochem., 8,53 (1974).

85. Stafford, H. A.: In Metabolism and regulation of secondary plant products. Pp. 53, London, 1974, Academic Press.
86. Stenlid, G.: Physiol. Plantarum, 21, 882 (1968).

87. Sutfield, R. and R. Wiermann: Z. Pflanzenphysiol., 79, 467 (1976).

88. Timberlake, C. F. and P. Bridle: In J. B. Harborne, T. J. Mabry and H. Mabry (eds.): The Flavonoids, Lond., 1975, Chapman and Hall.

89. Towers, G. H. N.: In D. H. Northcote (ed.): ATP International Reviews of Science. Biochemistry-Series I, Vol. 11, Baltirmore, 1974, University Park Press.

90. Van Sumere, C. F., H. De Pooter, A. Haider and M. Degrauw-Van Bussell: Phytochem., 12, 407 (1973).

91. Vichnewski, W., H. L. Filho, R. Murari and W. Herz: Phytochem., 16, 2028 (1977).

92. Wallis, P. J. and M. J. C. Rhodes: Phytochem., 16, 1891 (1977).

93. Zucker, M.: Plant Physiol., 40, 779 (1965).

Address: Prof. Dr. G. H. N. Towers, Botany Department, University of British Columbia, Vancouver, B. C., Canada 